\title{
Does Communicative Language Teaching Help Develop Students' Competence in Thinking Critically?
}

\author{
Junko Winch \\ University of Sussex
}

\begin{abstract}
Correspondence concerning this article should be addressed to Junko Winch, Sussex Centre for Language Studies, University of Sussex, Arts A057, Falmer, BN1 9SH, United Kingdom. E-mail: j.winch@sussex.ac.uk

Critical thinking is one of the non-subject related learning goals which students are expected to develop in British education. Undergraduate students are offered to study language through the Institution-Wide Language Programme (IWLP) in the UK and most language teachers use Communicative Language Teaching (CLT). Paying attention to these two facts, this study investigates if CLT helps develop students' critical thinking. Using Hofstede et al.'s educational culture as a framework, the underlying pedagogies for both CLT and critical thinking were identified and the similarities and differences are compared. It was concluded that CLT helps to develop students' critical thinking as it shares with critical thinking pedagogies and elements of an educational culture. However, the pedagogy of independence was not shared. It is suggested that language teachers should give students the opportunity to think for themselves during class in order to encourage students' independence using CLT.
\end{abstract}

Keywords: Communicative Language Teaching, critical thinking, educational culture, higher education, Hofstede's cultural taxonomy

\section{Introduction}

Critical thinking is considered essential at the doctoral level in British universities. However, critical thinking for undergraduate students may be considered as "desirable but not essential" among modern language teaching staff (Marin \& Pava, 2017) and it is not usually included in language assessment criteria. However, there are language teachers who advocate developing students' critical thinking in language teaching. Some students are equipped with critical thinking and trained to think critically in their previous education, while others are not. The gap in the capacity for critical thinking between the two may be great. On the other hand, in language education, the majority of language teachers have been teaching language using Communicative Language Teaching (CLT). Combining critical thinking and CLT, the research question of this paper was formed whether CLT may be able to contribute to the development of students' critical thinking in any way. The purpose of this study is to investigate any similarities or differences between critical thinking and CLT from cultural perspectives.

The definition of critical thinking and CLT will be discussed in the next section, followed by the theoretical framework, before comparing the similarities and differences of the underlying pedagogies of critical thinking and CLT.

\section{Critical thinking}

Critical thinking is primarily derived from Anglo-European paradigms (Tan, 2017) and has become a practice developed and promoted by Western English-speaking countries from the 1970s (Vandermensbrugghe, 2004). Its definition has been changing over time. A generation ago, teachers expressed the belief that the development of thinking capability was a by-product of subject-matter teaching and that all we had to do was follow the prescribed curriculum and thinking would flourish spontaneously (Raths et al., 1966). Even at the present time, 
its definition has broad parameters and lacks consensus over its meaning. Marin \& Pava (2017) investigated university English language teachers' view on critical thinking in the Colombian context. The findings showed that critical thinking is mainly considered as problem solving, which comprises higher order thinking skills. Moore (2013) also conducted interviews with university humanities academics on critical thinking in an Australian context. The findings showed that critical thinking is: 1 ) judgement; 2 ) a skeptical and provisional view of knowledge; 3) originality; 4) a careful and sensitive reading of text; 5) rationality; and 6) an ethical and activist stance. In this paper, critical thinking in higher education is operationally defined as: 1) originality/ creativity (Moore, 2013; Bailin et al., 1999); 2) careful and sensitive reading of text and think of beyond the text (Moore, 2013); 3) problem solving (Marin \& Pava, 2017); and 4) skills which you can train to obtain (Wasserman, 1987).

\section{CLT}

CLT also originates in Anglo Saxon countries (Song, 2019) and is the most recent and frequently employed language teaching approach. The definition of CLT also lacks consensus in its meaning. This is because CLT has been practised for over four decades, during which various developments have taken place. The history of CLT consists of classic and current versions (Richards, 2006, p. 6). The classic, "CLT started in the late 1970s in Europe and gained momentum in the early 1980s. Since then it has taken hold and acquired the status of a new dogma" (Hu, 2002, p. 94). CLT has "the CLT attitude" (Bax, 2003, p. 280), giving the implicit message to language teachers that "a country without CLT is somehow backward... CLT is not only "modern" but in fact the only way to learn a language properly" (Bax, 2003, p. 279): "The Communicative Approach is the way to do it, no matter where you are... CLT will work anywhere - the methodology is king" (Bax, 2003, p. 281). Bax criticises that CLT "assumes and insist that CLT is the whole and complete solution to language learning" and "assumes that no other method could be any good" (Bax, 2003, p. 280).

From its inception, the focus of CLT has been on communicative competence to "produce or understand utterances which are not so grammatical" (Campbell and Wales, 1970, p. 247). A question of whether communicative approach refers exclusively to communicative knowledge or includes grammatical competence was raised. This led CLT to evolve into three perspectives or theories: theory of basic communication skills; sociolinguistic perspective; and integrative theory. The theories of basic communication skills mainly focus on "oral communication to get along in or cope with" (Canale and Swain, 1980, p. 9) and "do not emphasise grammatical accuracy” (Canale and Swain, 1980, p. 9).

Current CLT is the latest development of classic CLT in communicative, grammatical and sociolinguistics competences. Howatt's (1984) "strong" and "weak" forms of CLT are a further development of communicative competence, which distinguishes the aim of CLT is "learning to use English" or "using English to learn it" (Ellis, 2012, p. 196). Byram's (1997) model of Intercultural Communicative Competence (ICC) is a further elaboration of sociolinguistic competence in CLT into the five "savoirs" associated with ICC. There is also a development in grammatical competence related to accuracy and error correction, with "the ultimate goal of learning is to be able to use the new language both accurately and fluently” (Richards, 2006, pp. 22-23).

In this paper, CLT is operationally defined as: 1) a student-centred class (Hu, 2002; Dörnyei, 2009); 2) use of communicative activities such as problem solving, role play, information gap and games ( $\mathrm{Hu}, 2002)$; and 3) "avoid(s) linguistic correction entirely" (Brumfit \& Johnson, 1979, p. 173).

It may sound challenging to compare CLT and critical thinking as one relates to language teaching approach and another relates to thinking and reasoning. However, a comparison of the origin of critical thinking and CLT shows that they both originate from Western, Anglophone concepts. This point is significant as it may imply the reason for similarities. In addition, they seem to relate to culture. Bailin et al. (1999) claim that "critical thinking is cultural artefact" (Bailin et al., 1999, p. 292) and Peter (2008) also argues that thinking and reasoning are not homogenous phenomena and different cultural forms of reasoning and argumentation exist. In previous studies, Winch (2013) investigated CLT using the underlying culture. Therefore, investigating the underlying pedagogies of critical thinking is also anticipated to go through a similar procedure. Thus, it is possible to find a link between CLT and critical thinking using underlying pedagogies. 


\section{Theoretical Framework}

Geert Hofstede is one of the leading academics on culture (Kirkman et al., 2006; Merkin et al., 2014). Despite some criticism (e.g., Baskerville, 2003; McSweeney, 2002; Spector, Cooper, \& Sparks, 2001; Taras \& Steel, 2009), "Hofstede's model has been used most often" (Merkin et al., 2014, p. 3). This study utilises Hofstede's framework as a basis of data collection and analysis. Hofstede et al.'s (2010) cultural taxonomy, which consists of five dimensions across two opposing poles, was chosen as the framework for this article. Their categorisation of a particular nationality may be too stereotypical and simplified as the reality is much more complex. Given that today's society consists of people with different heritages and preferences due to globalisation, it is difficult to generalise the cultural preferences of a particular nationality or heritage. However, we cannot dismiss that there is also some truth about Hofstede et al.'s labelling nationalities by culture. Furthermore, having two opposite poles of the spectrum is considered easier to compare and understand educational culture and underlying pedagogies of CLT and critical thinking.

Before introducing the dimensions of culture used in this study, the specific understanding of culture used in this study should be explained. Culture is based on layers such as family, school and corporation. Educational culture, which is the focus of this study, refers to a culture of school or teaching and learning. Educational culture is predominantly created by teachers and students within the classroom. It includes values, beliefs, appropriate behaviour, underlying pedagogies and assumptions on the relationship between the teacher and students and how this guides students to specific behaviour within the classroom.

Hofstede et al. (2010) divide cultures in five dimensions: large vs. small power distance; individualism vs. collectivism; masculinity vs. femininity; strong vs. weak uncertainty avoidance; and long-term vs. short-term. Among these, three dimensions, that is, individualism-collectivism, power distance and uncertainty avoidance are relevant for the focus in this study.

\section{Individualist vs. Collectivist and its Underlying Pedagogy}

Individualist and collectivist are defined as "the interests of the individual prevail over the interests of the group" (Hofstede et al., 2010, p. 91) and "the interest of the group prevails over the interest of individual" (Hofstede et al., 2010, p. 90), respectively. Generally speaking, Anglophone countries have an individualist society whereas Asian countries have a collectivist society (Dimmock, 2000).

Independence vs. dependence/interdependence. There are two influential key words and philosophers which influence teaching and learning between the West and Confucian countries. In the West, "independence" represents the philosophy of Socrates in the fifth century BC. The goal of the Socratic education is "to lead him (youth) to the truth by means of questioning" (Hinkel, 1999, p. 19). Questioning involves a one-to-one interaction and instruction. Socrates plays a role as "a midwife who helps to give birth to a truth" (Hinkel, 1999, p. 19). In the West where the Socratic pedagogical tradition is preferred, independence is considered important. Thus, overdependence, i.e. utterly dependent they cannot complete a task without help at virtually every step, is considered as inappropriate behaviour in an Anglophone educational culture, but dependence/interdependence may be appropriate in the Confuciun culture where values originated with Confucius in the sixth century BC. Unlike Socrates, "Confucius is asked questions by his students and responds with wisdom" (Hinkel, 1999, p. 19). This fosters a dependent relationship between the teacher and students. Tan (2017) claims that collectivist culture discourages independence and prefers dependence and interdependence. Dependence in teaching and learning values passive students and students' lack of criticality.

One-to-one interaction vs. one-to-whole group interaction. Examples of one-to-one interaction in teaching and learning include pair work, dialogue and tutoring. Pair work and dialogue are interaction between students whereas dialogue and tutoring are interaction between student and a teacher. The strength of interaction between students is that each pair can do their activities at their own pace and level compared whole class instruction. One-to-one interaction also stimulates students' active cognition by keeping students engaged through tailored learning.

Collectivist societies prefers to teach students in a whole class instruction or in groups. The teacher looks at a class as one group and interacts in a collectivist culture. Students educated in this culture are not familiar and 
comfortable with student-to-student interaction in class. Often turn-taking is combined with the whole class instruction as it gives equal opportunity to the students in the group.

\section{PD and its underlying pedagogy}

Power Distance (PD) is defined as "the extent to which the less powerful members of institutions and organisations within a country expect and accept that power is distributed unequally" (Hofstede et al., 2010, p. 61). To make this definition easier to understand and specific, the "powerful members" of institutions in a university language instruction context would be language teachers and "less powerful members" would be students. In this context, PD is defined as the extent to which students expect and accept that power is distributed unequally in favor of teachers. It is claimed that "many Asian societies are high PD cultures, while many Western societies have low PD values" (Dimmock, 2000, p. 47). Generally speaking, Western societies do not expect or accept that power is distributed unequally as much as Asian societies do.

Teacher centred vs. student-centred class. A teacher-centred class is a pedagogy consistent with a large power distance educational culture. Teacher centre class used in this study is defined as, "The teacher initiating all communication. Students in a class speak up only when invited to" (Hofstede et al., 2010, p. 69). Teachercentred orientation includes conceptions that teaching is about imparting information and transmitting knowledge (Pithers \& Soden, 2000). The strength of a teacher-centred class may be that it provides all students with the same educational opportunities for all. A potential weakness of a teacher-centred class is that learning requirements from individual students may be difficult to meet. On the other hand, a student-centred class is pedagogy of small power distance educational culture and usually refers a class where students are expected to take the initiative. Student-centred orientation includes beliefs that teaching is about imparting understandings, promoting conceptual change and intellectual development (Pithers \& Soden, 2000). The strength of a studentcentred class is to make students more proactive in learning. A potential weakness of a student-centred class is that they may not meet the needs of students who prefer passive learning approaches. Some might learn better by teachers presenting all the necessary important learning points rather than active learning.

\section{UA and its underlying pedagogy}

Uncertainty avoidance is defined as, "the extent to which the members of a culture feel threatened by ambiguous or unknown situations” (Hofstede et al., 2010, p. 191).

Creativity vs. control. Creativity and control seem to correlate with each other. As control is lessened in teaching, learners" creativity increases. Preference for one correct answer, error elimination and routinisation are pedagogical instruments for a strong uncertainty avoidance culture. The fields of study of mathematics and sciences usually adopt the one correct answer system as a common practice world-wide. It might be possible to say that students and teachers studying mathematics are likely to share a strong uncertainty avoidance culture compared to students and teachers from other departments, such as music and art. On the other hand, creativity and open-ended questions form a pedagogy for a weak uncertainty avoidance culture. An emphasis on creativity in teaching and learning means freedom from control or routine.

In an educational context, if students do not feel comfortable about unknown situations, they prefer a strong uncertainty culture. The Strong Uncertainty Avoidance Index (UAI) scores nations that try to avoid ambiguous situations wherever possible, whereas weak UAI scoring nations are not concerned about any unknown situations. According to Hofstede et al.'s UAI index by countries, Anglophone countries appear to be labelled as weak uncertainty avoidance countries whereas Asian countries are labelled as strong uncertainty avoidance countries. However, as Hofstede et al.'s model has been criticised as "essentialism" (Godwin-Jones, 2013), it should be emphasised that there are various types of people with different perspectives and beliefs regardless of wherever they live. For example, some people may have already succumbed to strong uncertainty avoidance educational culture and others may have already learned to be dependent on the thinking of others and may falter when asked to function on their own initiative.

These three dimensions and their underlying pedagogies became the framework of the comparison between CLT and critical thinking. This study was stimulated to answer the research question, "Does CLT help develop students' critical thinking". 


\section{Materials and Methods}

\section{Materials}

The data regarding the educational culture (specifically individualist-collectivist, power distance and uncertainty avoidance) and underlying pedagogies of CLT and critical thinking (CT) were collected from a total of 50 journal articles (JA) and books (B) from the field of Linguistics, English Language, Education, Psychology, Social Studies, Business Studies and Management (See Appendix 1). The dates for these studies range between 1972 and 2019. This study does not involve human participants.

\section{Methods}

Underlying pedagogies were chosen to be the mediums to identify educational culture of CLT and critical thinking. Educational culture and underlying pedagogies, especially, in critical thinking and CLT, are currently under-researched areas. Many studies related using Hofstede's cultural taxonomy have been conducted in International Business studies and Management (Kirkman et al, 2002). By cross-relating the literature data and educational culture and its underlying pedagogies on three dimensions, it is possible to identify the underlying pedagogies and educational culture of critical thinking and CLT, related to the research questions. The definition of critical thinking and CLT discussed in the first part of this article is used throughout this article.

\section{Procedure}

The procedure involved a two-tier indirect investigation. The first stage used the journal articles and books mentioned above, with the aim of identifying the characteristics or underlying pedagogies in CLT and critical thinking. Identifying underlying pedagogies enable us to determine the educational culture of critical thinking and CLT. It is an indirect method as identification of educational culture is via underlying pedagogies. Statements which match with each underlying pedagogy (e.g. student-centred or teacher-centred, independence and oneto-one interaction, creativity or correct answers) related to critical thinking and CLT were scrutinised in 50 journals and books. These results will be summarised according to each dimension (individualist-collectivist, power distance and uncertainty avoidance). In the second stage, the similarities and differences of the underlying pedagogies and educational culture between CLT and critical thinking are compared and analysed, which will be presented with a table in the Results and Discussion.

\section{Results and Discussion}

This section discusses the findings of underlying pedagogies of CLT and critical thinking, which also reveal their educational culture.

\section{CLT}

Winch (2013) investigated the underlying pedagogies and educational CLT by comparing traditional teaching and CLT. This section is based on Winch's (2013) findings. CLT adopts the following dimensions of educational culture: small power distance, weak uncertainty avoidance, and individualism. These are justified and supported with evidence of CLT"s underlying pedagogies (e.g. student-centred or teacher-centred, independence and oneto-one interaction, creativity or correct answers).

Firstly, CLT resembles a small power distance culture claimed as "student-centred CLT (Dörnyei, 2009, p. 41) "is firmly opposed to teacher dominance in the classroom" (Hu, 2002, p. 95). Thus, student-centred orientation is an underlying pedagogy of a small power distance educational culture. In most language class, teacher tells students to practise talking with their partner, which is demonstrated student-centred class. Secondly, CLT is a characteristic of Hofstede's weak uncertainty avoidance culture because it values creativity. Some of CLT"s favourite tasks include problem solving and role playing (Hu, 2002), which give students opportunities to do creative role play or creative ideas in dealing with a problem solving task. 
In addition, CLT's characteristics include a tolerance for errors, which implies the weak uncertainty avoidance culture: for example, "learners are not being constantly corrected. Errors are regarded with greater tolerance" (Littlewood, 1981, p. 94). CLT "avoid(s) and linguistic correction entirely" (Brumfit \& Johnson, 1979, p. 173). This is consistent in speaking and grammar skills: in speaking, "errors are tolerated and seen as a natural outcome of the development of communication skills" (Larsen-Freeman, 2000, p. 127), in grammar, it "does not emphasise grammatical accuracy" (Canale and Swain, 1980, p. 9).

Thirdly, CLT focuses on an individual student, thereby making it a culture of individualism. In language classes, students usually work on these activities in pairs in CLT. This gives students a one-to-one interaction. For example, one of the CLT's favorite activities, information gaps, is ideal to do in pairs.

\section{Critical Thinking}

Weak UA: fallacy of correct answer, tolerance for uncertainty and creativity. According to Hofstede et al. (2010), the underlying pedagogy of a weak uncertainty avoidance culture in school is: "students are comfortable with open-ended learning and concerned with good discussion", "teachers may say "I don't know"” (Hofstede et al., 2010, p. 208). On the other hand, the underlying pedagogy of a strong uncertainty avoidance culture at school includes: "students are comfortable in structured learning and concerned with right answers" and "teachers are supposed to have all the answers" (Hofstede et al., 2010, p. 208). "Correct" and "open-ended" answers are associated with "control" and "freedom", respectively. Control is an educational cultural value of strong UA. Examples of controlled pedagogies include one-correct answer type questions (multiple choice and True/False questions), routinisation, rehearsed activities, rote learning, recitation, and strong discipline. Surprisingly, "control" pedagogy existed in American schools before 1860 to develop intelligent mass citizenship (Oaks, 1985). On the other hand, underlying pedagogy of weak UA is "freedom". "Freedom" pedagogy is demonstrated by open-ended learning, open-ended questions and creativity. From the above discussion, a one correct answer system represents an underlying pedagogy of strong uncertainty avoidance culture and creativity represents an underlying pedagogy of weak uncertainty avoidance culture.

Three weak UA pedagogies are discussed related to critical thinking: 1) "fallacy of right answers"; 2) "tolerance of ambiguity and uncertainty"; and 3) "creativity". As for point 1, the "fallacy of right answer" (weak UA) is included in one of eight fallacies in teaching critical thinking (Sternberg, 1987), which supports the link between fallacy of right answer and critical thinking. Pithers \& Soden (2000) assert that students are unable to enhance critical thinking if they are unable to "tolerate ambiguity and uncertainty". Thus, the link between "tolerate ambiguity and uncertainty" (weak UA) and critical thinking is addressed in point 2 . Similarly, the link between creativity (Weak UA) and critical thinking is addressed in point 3 as follows: "critical thinking often requires imagining possible consequences, generating original approaches and identifying alternative perspectives. Thus creativity plays an important role in thinking critically" (Bailin et al., 1999, p. 288). From these three examples, critical thinking is associated with a weak UA.

Small PD: student-centred orientation. The underlying pedagogy of power distances is either a teachercentred or a student-centred class (Winch, 2015). The underlying pedagogy of a large PD is a teacher-centred class, which considers that "teachers are gurus who transfer personal wisdom", "students treat teachers with respect" and "teachers are expected to take all initiatives in class" (Hofstede et al., 2010, p. 72). On the other hand, the underlying pedagogy of a small power PD is a student-centred class which considers that "teachers are experts who transfer impersonal truth", "students treat teachers as equals" and "teachers expect initiatives from students in class” (Hofstede et al., 2010, p. 72).

The role of a teacher and students in a student-centred and a teacher-centred classroom is different. In a studentcentred class, "teaching is about facilitating understandings, promoting conceptual change and intellectual development" (Pithers \& Soden, 2000, p. 247). The role of the teacher in the Socrates education is described as "midwife". The teacher's "midwife" role nowadays is referred to as the "facilitator", as Sternberg (1987) states that "we must let students teach themselves to a large extent. We need to serve not strictly as teachers, but as facilitators" (p. 459).

On the other hand, the role of the teacher in the Confucian educational system is described as a "transmitter". Confucius education is summarised as follows: 
Confucius is asked questions by his students and responds with wisdom. Rather than a midwife who helps give birth to a truth that lies within, he is a messenger who transmits the wisdom of the ancient (Hinkel, 1999, p. 19).

In a teacher-centred class, teacher"s role in learning is considered important which emphasises the "transmission" model, i.e. "teaching is about imparting information or transmitting structured knowledge" (Pithers \& Soden, 2000, p. 247). It is unlikely to develop students' critical thinking in the translation model as "more completely they accept the passive role imposed on them, the more they tend simply to accept to the world as it is" (Freire, 1972, p. 47). "Students" automatic thinking closure is likely to occur when the teacher doesn't give the student a chance to think; when the teacher does the thinking by showing or telling the pupil what to do; when the teacher cuts off the student's response" (Wassermann, 1987, p. 464).

On the other hand, a student-centred class is the pedagogy of small PD and related to critical thinking. According to Pithers \& Soden (2000), "The student-centred orientation is more consistent with approaches for developing student thinking" (Pithers \& Soden, 2000, p. 247). This supports the link between student-centred orientation and critical thinking. To create student-centred class, a teacher should play of the role of a facilitator: "we need to serve not strictly as teachers, but as facilitators" (Sternberg, 1987, p. 459).

Individualist educational culture: dialogue and independence. Where sensitivity to the individual is considered of paramount importance in a society, one-to-one instruction, interaction and independence are an ideal individualist culture pedagogy. Dialogue and tutoring are examples of one-to-one interaction. Mason (2008) implies the link between dialogue and critical thinking as follows: dialogue with others, who are different, with different worldviews and cultural backgrounds, is essential feature of critical thinking.

Critical thinking is discussed using two pedagogies: dialogue and independence. Dialogue provides one-to-one interaction/instruction and represents the underlying pedagogy of individualist educational culture. The link between critical thinking and dialogue is demonstrated by Bailin et al. (1999) who state: "critical thinking very often takes place in the context of persons thinking things through together by means of discussion and dialogue" (p. 289). Dialogue gives students opportunities to encounter other views, which may present challenges to the students' own perspectives. The strength of interaction between a student and a teacher is when the teacher uses a critical questioning approach with a student, which is characterised through the verbalisation of thought process using Vygotskian notion of language as a tool for thought (Ryan \& Louie, 2007). This challenge also leads to acceptance of multiple perspectives, comparing similarities and differences. Critical thinking confirms students' dogmatism, i.e., convincing that their belief is correct. An example of students' lack of criticality relates to independence. If students are encouraged to depend on a teacher who transmits knowledge, students do not think for themselves and blindly believe teachers and textbooks that they never make mistakes.

The link between critical thinking and independence is demonstrated as follows: "students must learn to teach themselves" (Pithers \& Soden, 2000, p. 243); "students must ultimately teach themselves, for they must be responsible for finding out what methods of problem finding and problem-solving work for them" (Sternberg, 1987, p. 459). Independence is the preferred value in individualist cultures. However, students' critical thinking may not be valued in the collectivist societies due to collectivist educational culture.

Table 1

Comparison of CLT and Critical Thinking

\begin{tabular}{lll}
\hline & \multicolumn{1}{c}{ CLT } & \multicolumn{1}{c}{ Critical thinking } \\
\hline Power distance (PD) & $\begin{array}{l}\text { Small PD } \\
\text { (Student-centred) }\end{array}$ & $\begin{array}{l}\text { Small PD } \\
\text { (Student-centred) }\end{array}$ \\
\hline Uncertainty Avoidance (UA) & $\begin{array}{l}\text { Weak UA } \\
\text { (Creativity) }\end{array}$ & $\begin{array}{l}\text { Weak UA } \\
\text { (Creativity, fallacy of correct answer, tolerance for uncertainty) }\end{array}$ \\
\hline Individualist vs Collectivist & $\begin{array}{l}\text { Individualist } \\
\text { (One-to-one interaction, pair work) }\end{array}$ & $\begin{array}{l}\text { Individualist } \\
\text { (One-to-one interaction, dialogue) } \\
\text { (Independence) }\end{array}$ \\
\hline
\end{tabular}

To summarise the educational culture and underlying pedagogy of critical thinking, it adopts a Small PD, Weak UA, and Individualism. With regards to the PD dimensions, critical thinking adopts a Small PD as it has two 
underlying pedagogies of Small PD: student-centred class and teacher's role as a facilitator. With regards to UA dimensions, critical thinking adopts weak UA as it has three underlying pedagogies of tolerance for ambiguity, the fallacy of the right answer and creativity. With regards to the individualism vs. collectivism dimension, critical thinking adheres to individualism as it has an underlying pedagogy of dialogue and independence.

As for the similarities of educational culture and underlying pedagogies, individualism, weak uncertainty avoidance and small power distance were shared in all dimensions between CLT and critical thinking. If there are more similarities than differences, more strongly we can say that CLT helps develop students' critical thinking. All underlying pedagogies in the three dimensions were shared between CLT and critical thinking with an exception of a pedagogy of individualist dimension. In individualist culture dimension, one-to-one interaction (pair work) and one-to-one instruction (dialogue) were shared between CLT and critical thinking, both of which belong to individualist culture. In the UA dimension, "creativity" was shared between CLT and critical thinking, which belongs to weak UA dimension. Furthermore, "tolerance for error" in CLT and "tolerance for ambiguity" in critical thinking were considered similar pedagogy and they were shared between CLT and critical thinking. In the PD dimension, student-centred orientation was shared in both CLT and critical thinking, which belong to small PD. The only pedagogy which was not shared between CLT and critical thinking was "independence" in critical thinking, which belongs to individualist culture. Only critical thinking has independence, but CLT did not share it.

\section{Conclusion}

The research question of this paper was whether CLT helps to develop students' critical thinking. It is possible to conclude that CLT helps to develop students' competence in critical thinking, considering the similarities and differences between critical thinking and CLT from the above discussion.

However, independence was not clearly shared between CLT and critical thinking. Teachers who support the role of "midwife" give students opportunities to think, to overcome uncertainty, to use creativity and to think on their own. This process is also called problem solving. On the other hand, teachers who support the role of "transmitter" give students the answers straight away and may hinder students' independence by not giving students opportunities to think. Students who are spoon-fed in learning are not given the opportunity to think for themselves. Students' independence is not encouraged in teaching and learning where the transmission model is preferred. However, respect should be given to different educational cultures which have different approaches to learning and each culture has developed specific systems for disciplining thinking skills and teaching approaches.

\section{References}

Bailin, S., Case, R., Coombs, J. R. \& Daniels, L. B. (1999). Conceptualizing critical thinking. Journal of Curriculum Studies, 31(3), 285-302. doi: https://doi.org/10.1080/002202799183133.

Baskerville, R. F. (2003). Hofstede never studied culture. Accounting, Organizations and Society, 28(1), 1-14.

Bax, S. (2003). The end of CLT: A content approach to language teaching. ELT Journal, 57(3), 278-287. doi: https://doi.org/10.1093/elt/57.3.278

Brumfit, C. J., \& Johnson, K. (1979). The communicative approach to language teaching. Oxford, UK: Oxford University Press.

Canale, M., \& Swain, M. (1980). Theoretical bases of communicative approaches to second language teaching and testing. Applied Linguistics, 1(1), 3-47. doi: https://doi.org/10.1093/applin/I.1.1

Dimmock, C. (2000). Designing the learning-centred school - A cross-cultural perspective. London, UK: Routledge Farmer.

Dörnyei, Z. (2009). Communicative language teaching in the 21st century: The "principled communicative approach". Perspectives, 36(2), 33-43.

Ellis, R. (2012). Language teaching research and language pedagogy. Chichester, UK: Wiley-Blackwell.

Freire, P. (1972). Pedagogy of the oppressed. New York, NY: Penguin Books. 
Godwin-Jones, R. (2013). Integrating intercultural competence into language learning through technology. Language Learning \& Technology, 17(2), 1-11. doi: https://doi.org/10125/44318

Hinkel, E. (1999). Culture in second language teaching and learning. Cambridge, UK: Cambridge University Press.

Hofstede, G., Hofstede, G. J., \& Minkov, M. (2010). Cultures and organizations - Software of the mind. New York, NY: McGraw-Hill Book Company.

Hu, G. (2002). Potential cultural resistance to pedagogical imports: The case of communicative language teaching in China. Language Culture and Curriculum, 15(2), 93-105. doi: https://doi.org/10.1080/07908310208666636.

Kirkman, B. L., K. B. Lowe, \& C. B. Gibson. (2006). A quarter century of culture's consequences: A review of empirical research incorporating Hofstede's cultural values framework. Journal of International Business Studies, 37(3), 285-320. http://dx.doi. org/10.1057/palgrave.jibs.8400202

Larsen-Freeman, D. (2000). Techniques and principles in language teaching (2nd ed.). Oxford, UK: Oxford University Press.

Littlewood, W. (1981). Communicative language teaching - An introduction. London, UK: Cambridge University Press.

Marin, M., \& Pava, L. (2017). Conceptions of critical thinking from university EFL teachers. English Language Teaching, 10(7), 78-88. doi: https://doi.org/10.5539/elt.v10n7p78

McSweeney, B. (2002). Hofstede's model of national cultural differences and their consequences: A triumph of faith - A failure of analysis. Human Relations, 55(1), 89-118.

Merkin, R., Taras, V., \& Steel, P. (2014). State of the art themes in cross-cultural communication research: A systematic and meta-analytic review. International Journal of Intercultural Relations, 38, 1-23. doi. org/10.1016/j.ijintrel.2013.10.004

Moore, T. (2013). Critical thinking: seven definitions in search of a concept. Studies in Higher Education, 38(4), 506-522. doi: https://doi.org/10.1080/03075079.2011.586995.

Oaks, J. (1985). Keeping track. New Haven, Connecticut: Yale University Press.

Peters, M. (2008). Kinds of thinking, styles of reasoning. In M. Mason (Ed.), Critical thinking and learning (pp. 1224). Oxford, UK: Blackwell Publishing.

Pithers, R. T., \& Soden, R. (2000). Critical thinking in education: a review. Educational Research, 42(3), 237-249. doi: https://doi.org/10.1080/001318800440579.

Raths, L. E., Wasserman, Jonas, S. A., \& Rothstein, A. (1966). Teaching for critical thinking: Theory and application. Columbus, Ohio: Charles-Merrill.

Richards, J.C. (2006). Communicative language teaching today. Cambridge, UK: Cambridge University Press.

Ryan, J. \& Louie, K. (2007). False dichotomy? Western and Confucian concepts of scholarship and learning. Educational Philosophy and Theory, 39(4), 404-417. doi: https://doi.org/10.1111/j.1469-5812.2007.00347.x.

Song, B. (2019). The research on effectiveness of communicative language teaching in China. Asian Culture and History, 11, 1-10. doi: https://doi.org/10.5539/ach.v11n11n1p1

Spector, P. E., Cooper, C. L., \& Sparks, K. (2001). An international study of the psychometric properties of the Hofstede Values Survey Module 1994: A comparison of individual and country/province level results. Applied Psychology: An International Review, 50(2), 269-281.

Sternberg, R. J. (1987). Teaching critical thinking: Eight easy way to fail before you begin. Phi Delta Kapp, 68(6), $456-459$.

Tan, C. (2017). A confucian conception of critical thinking. Journal of Philosophy of Education, 51(1), 331-343. doi: https://doi.org/10.1111/1467-9752.12228

Taras, V., \& Steel, P. (2009). Beyond Hofstede: Challenging the ten testaments of cross-cultural research. In C. Nakata (Ed.), Beyond Hofstede: Culture frameworks for global marketing and management (pp. 40-61). Chicago, Ill: Macmillan/Palgrave.

Vandermensbrugghe, $J$ (2004). The unbearable vagueness of critical thinking in the context of Anglo-Saxonisation of Education. International Education Journal, 5(3), 417-421.

Wassermann, S. (1987). Teaching for thinking: Louis. E. Raths revisited. Phi Delta Kappa, 68(6), 460-466.

Winch, J. (2013). An investigation of the impact of Japanese educational culture: Japanese language learning in an international context. Saarbrücken, Germany: Lap Lambert Academic publishing.

Winch, J. (2015). Are international students' preferred pedagogy influenced by their educational culture? International Journal of Education and Literacy Studies, 3(2), 1-6. doi: https://doi.org/10.7575/aiac.ijels.v.3n.2p.1 


\section{Appendix 1}

List of studies

\begin{tabular}{|c|c|c|c|c|}
\hline & Study & Type & & Journal name \\
\hline 1 & Moore, T. (2013) & JA & CT & Studies in Higher Education \\
\hline 2 & Hofstede et al (2010) & B & Theoretical framework & \\
\hline 3 & Dimmock (2000) & B & IND & \\
\hline 4 & Hinkel (1991) & B & IND & \\
\hline 5 & Pithers \& Soden (2000) & JA & $\mathrm{PD}$ & Educational Research \\
\hline 6 & Sternberg (1987) & JA & $\mathrm{PD}$ & Phi Delta Kappan \\
\hline 7 & Freire (1972) & B & $\mathrm{PD}$ & \\
\hline 8 & Wassermann (1987) & JA & $\mathrm{PD}$ & Phi Delta Kappan \\
\hline 9 & Godwin-Jones (2013) & JA & Cultural framework & Language Learning \& Technology \\
\hline 10 & Oaks (1985) & B & UA & \\
\hline 11 & Tan (2017) & JA & CT & Journal of Philosophy of Education \\
\hline 12 & Raths et al (1966) & JA & $\mathrm{CT}$ & \\
\hline 13 & Marin \& Pava (2017) & JA & CT & English Language Teaching \\
\hline 14 & Song (2019) & JA & CLT & Asian Culture and History \\
\hline 15 & $\mathrm{Hu}(2002)$ & JA & CLT & Language Culture and Curriculum \\
\hline 16 & Dörnyei & JA & CLT & Perspectives \\
\hline 17 & Brumit \& Johnson (1979) & B & CLT & \\
\hline 18 & Bailin et al (1999) & JA & CT & Journal of Curriculum Studies \\
\hline 19 & Winch (2013) & B & CLT & \\
\hline 20 & Winch (2015) & JA & $\mathrm{PD}$ & International Journal of Education and Literacy Studies \\
\hline 21 & Kirkman et al (2006) & JA & Theoretical framework & Journal of International Business Studies \\
\hline 22 & Merkin et al (2014) & JA & Theoretical framework & International Journal of Intercultural Relations \\
\hline 23 & Baskerville (2003) & JA & Theoretical framework & Organizations and Society \\
\hline 24 & McSweeney (2002) & JA & Theoretical framework & Human Relations \\
\hline 25 & Spector, Cooper \& Sparks (2001) & JA & Theoretical framework & Applied Psychology: An International Review \\
\hline 26 & Vandermensbrugghe (2004) & JA & CT & International Education Journal \\
\hline 27 & McGuire (2007) & JA & CT & Asia Pacific Education review \\
\hline 28 & Ryan \& Louie (2007) & JA & IND & Education Philosophy and Theory \\
\hline 29 & Tan (2015) & JA & IND & Education Philosophy and Theory \\
\hline 30 & Cortazzi \& Jin (2010) & $\mathrm{C}$ & CT & Conference paper \\
\hline 31 & Mason (2008) & B & $\mathrm{CT}$ & \\
\hline 32 & Turner (2006) & JA & CT & International Journal o Management Education \\
\hline 33 & Evers (2008) & & & \\
\hline 34 & Ennis & JA & CT & Theory Into Practice \\
\hline 35 & Murawski (2014) & JA & CT & Journal of Learning in Higher Education \\
\hline 36 & Larsen-Freeman (2000) & B & CLT & \\
\hline 37 & Cho \& Kim (2018) & JA & CLT & TESOL Journal \\
\hline 38 & Humhries \& Burns (2015) & JA & CLT & ELT Journal \\
\hline 39 & Christopher (2012) & B & IND, PD & \\
\hline 40 & Chalmers \& Volet (1997) & JA & CT & Higher Education Research \& Development \\
\hline 41 & Brumfit et al (2005) & JA & CT & International Journal of Applied Linguistics \\
\hline 42 & Flores et al (2012) & JA & CT & Educational Philosophy and Theory \\
\hline
\end{tabular}




\section{JUNKO WINCH}

\begin{tabular}{lllll}
43 & Paul (2005) & JA & CT & New Direction for Community Colleges \\
44 & Littlewood (1991) & JA & IND, CT & \\
45 & Ford et al (2004) & JA & CT & Social Work Education \\
46 & Ford et al 2005) & JA & CT & Social Work Education \\
47 & Barnett (1997) & B & CT & \\
48 & Zhao, Pandian \& Singh (2016) & JA & CT & English Language Teaching \\
49 & Chaffee (1992) & JA & CT & Journal of Developmental Education \\
50 & Mok (2010) & JA & CT & The Asian EFL Journal Quarterly \\
\hline
\end{tabular}

